\title{
The effects of seaweed extracts and the applications of vermiwash on organic lettuce (Lactuva sativa L.) seedlings
}

\author{
Metin Aydın (D) ${ }^{1}$, Murat Demirsoy (iD) ${ }^{1 *}$ \\ ${ }^{1}$ Selçuk University, Sarayönü Vocational School, Department of Plant and Animal Production, 42430, Konya, Turkey
}

\begin{abstract}
In this study, it is aimed to enhance organic seedling cultivation to levels at which it can compete with its conventional counterparts both in quality and growth process of the seedling. To this end, seaweed (SW) and vermiwash (V) were employed in the trial as well as their various doses and blends. 16 different doses and blends including the control group each of which were allocated three seedlings were conducted based on the triplicate principal. At the end of the process, the dry weight of the plants' root, stem and leaves was identified. The rise in the dry weight of the root, stem and the leaves resulting from the raised doses of seaweed and vermiwash in individual practices has revealed the positive and direct outcomes of the fertilizers on the plant growth. Much as seaweed provided the lowest leaf weight ratio (LWR), it yields the highest LWR. The lowest root weight ratio (RWR) is 0.1671 in SW2 application, whereas the highest leaf weight is 0.8329 in SW2. As a result of the trials, SW3 application shines out on the basis of the total dry weight $(0.3125 \mathrm{~g})$ of the lettuce seedlings. In study highest quality index of seedlings (QI) was determined in SW3 applications (0.1787). With respect to the LWR properties, being an important criterion for the lettuce itself and the dry matter for the seedling quality, seaweed applications have been concluded to be advisable.
\end{abstract}

\section{ARTICLE HISTORY}

Received: 23 March 2020

Accepted: 02 April 2020

\section{KEYWORDS}

Seaweed

Vermiwash

Seedling

Earliness

Growth

\section{* CORRESPONDING \\ mdemirsoy@selcuk.edu.tr}

\section{Introduction}

According to 2019 data, in our country 499766 tons of lettuce are produced that including 199491 tons, 215728 tons and 85547 tons of which are leaf lettuce (curly lettuce), head lettuce and iceberg respectively (TUIK, 2020). When compared based on the proportions of seedling types grown lettuce ranks the second in Turkey (Anonymous, 2020). In cultivation, fertilization is one of the most important processes exerting an influence on the amount of a given plant's quality. Due to the recent excessively artificially chemical input, medical concerns have skyrocketed and environmentally friendly cultivation systems have made a dramatic comeback in the face of the chemical residues (Yanmaz et al., 2020). In this respect, the combination of organic and chemical fertilizers as well as soil regulators, rather than their single use have proved to yield better results (Demirtaş et al., 2012; Kandemir et al., 2017). Instead of synthetic chemicals exploited to secure healthy and prompt growth of plants, many facilities are using seaweed solutions in order to provide natural, healthy, faster and highly efficient plant growth (Godlewska et al., 2016; Mzibra et al., 2018).

Liquid extract obtained from marine algae have been used over the past 40 year on various plants to encourage growth and improving. Interest seaweed concentrates in agricultural system is focused on their use as an inexpensive source of naturally occurring plant growth regulator. The algae or seaweeds are a group of primitive organisms with no have true roots, stems and leaves. However, they are one of the import marine living resources with of enormous commercial importance. Seaweed products are best known for their auxin and cytokinin contents, as these endogenous hytohormones are liable for cell division and root and shoot elongation, respectively. A sufficient level of potassium, nitrogen, growth promoting hormones, micronutrients, humic acids etc. present in seaweeds make it as excellent manure. Seaweed fertilizer besides increasing the soil fertility increases the moisture containment capacity and procures sufficient trace metals thereby improving the soil structure (Türkmen and $\mathrm{Su}, 2019$ ). Algs are of paramount importance owing both to their durability in salty atmosphere and to their high protein, vitamin and mineral content. Much as they were employed for various purposes throughout history, fertilization is the prime realm of the algs' use (Akyurt et al., 2011). Though formerly used in solid form, many firms today have increased and promoted the algs' liquid extract forms (Duan, 2013).

Some researchers found out that the functions of pathogens and insects in the soil are necessary for plants to thrive, there by developing vermicompost to this end (Arancon et al., 2006). In several studies, even a slight amount of vermicompost was observed to have implemented a favorable impact on the germination, seedling growth and ornament plants, besides yielding a supplementary effect on 
the offshoot and leaf growth under greenhouse conditions (Gutiérrez-Miceli et al., 2007; Hameeda et al., 2007).

\section{Materials and methods}

This research has been carried out in the polycarbonate greenhouse in the Sarayönü vocational high school within Selçuk University in 2019. As the plant bed, three units of peat and a unit of pearlite have been employed. Various doses of seaweed extract, vermiwash and their different combinations have been applied in randomly arranged blocks. The proportions of the seaweed extract and the vermiwash used in the research are given in Table 1 . The trial plants were removed to be subject to quantitative measurements once they grew enough to have 3-4 leaves. In each trial, plants were removed in groups of three delicately enough not to cause any damage and washed off their dirt. Their roots were cut at their intersection with the stem as well as the leaves off the stem removing the stalks together.

The identification of the plants' biomass (g); roots, stems and the leaves of each seedling were dried one by one in 80 ${ }^{\circ} \mathrm{C}$ about 72 hours in a JSON-150 drying oven. Subsequent to this process, their dry weight was measured through an Precisa XB 220A assay balance with 220 g capacity and $0.0001 \mathrm{~g}$ delicacy, resulting the proportions of the root, stem and the leaves using the acquired data. In the light of the data, their quantitative analysis was conducted in accordance with Uzun (1996). Growth parameters and the calculation models are presented in Table 2.

Morphological characteristics of seedling quality the following formula were used in accordance with Dickson et al. (1960) and Öztekin and Kevser (2019). The measures were used: total plant dry weight (TPDW), leaf dry weight (LDW) and root dry weight (RDW) in grams on an oven-dry basis; root collar seedling diameter (SD) in millimeters; and seedling height $(\mathrm{SH})$ in centimeters.

Quality index of seedlings $(\mathrm{QI})=\mathrm{TPDW} /((\mathrm{SH} / \mathrm{SD})+(\mathrm{LDW} /$ $\mathrm{RDW})$ )

Table 1. Seaweed extract, vermiwash and their different mixing ratios.

\begin{tabular}{|l|c|}
\hline Application & Application Rate \\
\hline SW1 & $100 / 100 \mathrm{ml} \mathrm{L}^{-1}$ \\
\hline SW2 & $200 / 100 \mathrm{ml} \mathrm{L}^{-1}$ \\
\hline $\mathrm{SW} 3$ & $300 / 100 \mathrm{ml} \mathrm{L}^{-1}$ \\
\hline $\mathrm{V} 1$ & $100 / 100 \mathrm{ml} \mathrm{L}^{-1}$ \\
\hline $\mathrm{V} 2$ & $200 / 100 \mathrm{ml} \mathrm{L}^{-1}$ \\
\hline $\mathrm{V} 3$ & $300 / 100 \mathrm{ml} \mathrm{L}^{-1}$ \\
\hline $\mathrm{V} 1+\mathrm{SW} 1$ & $100 / 100 \mathrm{ml} \mathrm{L}^{-1}+100 / 100 \mathrm{ml} \mathrm{L}^{-1}$ \\
\hline $\mathrm{V} 1+\mathrm{SW} 2$ & $100 / 100 \mathrm{ml} \mathrm{L}^{-1}+200 / 100 \mathrm{ml} \mathrm{L}^{-1}$ \\
\hline $\mathrm{V} 1+\mathrm{SW} 3$ & $100 / 100 \mathrm{ml} \mathrm{L}^{-1}+300 / 100 \mathrm{ml} \mathrm{L}^{-1}$ \\
\hline $\mathrm{V} 2+\mathrm{SW} 1$ & $200 / 100 \mathrm{ml} \mathrm{L}^{-1}+100 / 100 \mathrm{ml} \mathrm{L}^{-1}$ \\
\hline $\mathrm{V} 2+\mathrm{SW} 2$ & $200 / 100 \mathrm{ml} \mathrm{L}^{-1}+200 / 100 \mathrm{ml} \mathrm{L}^{-1}$ \\
\hline $\mathrm{V} 2+\mathrm{SW} 3$ & $200 / 100 \mathrm{ml} \mathrm{L}^{-1}+300 / 100 \mathrm{ml} \mathrm{L}^{-1}$ \\
\hline $\mathrm{V} 3+\mathrm{SW} 1$ & $300 / 100 \mathrm{ml} \mathrm{L}^{-1}+100 / 100 \mathrm{ml} \mathrm{L}^{-1}$ \\
\hline $\mathrm{V} 3+\mathrm{SW} 2$ & $300 / 100 \mathrm{ml} \mathrm{L}^{-1}+200 / 100 \mathrm{ml} \mathrm{L}^{-1}$ \\
\hline $\mathrm{V} 3+\mathrm{SW} 3$ & $300 / 100 \mathrm{ml} \mathrm{L}^{-1}+300 / 100 \mathrm{ml} \mathrm{L}^{-1}$ \\
\hline Control & $\mathrm{No} \mathrm{application}$ \\
\hline SW & \\
\hline
\end{tabular}

SW: Seaweed extract. V: vermiwash

The data acquired from the trial went through a variance analysis in SPSS v.22.0 program in compliance with the randomly arranged blocks and the discrepancy between the averages were compared through the Duncan test at a scale of $\mathrm{p}<0.05$.

Table 2. The plants growth parameters for quantitative analysis (Uzun, 1996).

\begin{tabular}{|l|l|}
\hline $\begin{array}{l}\text { Leaf weight ratio } \\
\text { (LWR) }\end{array}$ & $\begin{array}{l}\text { Total leaf dry weight }(\mathrm{g}) / \text { Total plant dry } \\
\text { weight }(\mathrm{g})\end{array}$ \\
\hline $\begin{array}{l}\text { Root weight ratio } \\
\text { (RWR) }\end{array}$ & $\begin{array}{l}\text { Total root dry weight }(\mathrm{g}) / \text { Total plant dry } \\
\text { weight }(\mathrm{g})\end{array}$ \\
\hline
\end{tabular}

\section{Results and discussion}

When the data belonging to the lettuce seedlings were analyzed, dry root weight was found to be the highest with 0.0569 on SW3 application. In parallel with this finding, dry leaf weight was observed to be $0.2556 \mathrm{~g}$ and the lowest property was seen on the control group with $0.0935 \mathrm{~g}$ as presented on Table 3. Demir et al. (2006), has revealed that dispersible algae materials applied on tomato, pepper and aubergine have a positive impact on the germination of these plants. The highest entire seedling total dry weight of the lettuce plant was identified as $0.3125 \mathrm{~g}$ on SW3 application, which is quite promising. On the other hand, the lowest dry weight was observed in the control group with the property of $0.1189 \mathrm{~g}$ (Table 3). Employed for the identification of the root and leaf properties, SW3 application proved advisable on the basis of the dry mass property which is among the crucial criteria in terms of seedling quality. Türkmen and $\mathrm{Su}$ (2019), detected that the turning the seaweed liquid fertilizer combined by zeolite into a valuable product to be used in agriculture is possible. This product can be used as fertilizer in ecological agriculture systems because it can't be limited and is natural origin. Besides, seaweed extract has been discovered to be rich in some growth hormones (auxin and cytokine) and micro nutrient elements ( $\mathrm{Fe}, \mathrm{Cu}, \mathrm{Zn}, \mathrm{Mo}, \mathrm{Co}$, $\mathrm{Mn}$ and Ni) as well as vitamins.

When the root and leaf weight ratio figures are assessed, no application shines out statistically. The highest root weight ratio was detected on $\mathrm{V} 2+\mathrm{SW} 1$ application with the property of 0.2514 . As for the lowest, it was detected on SW2 with the property of 0.1671 (Fig 1). Total dry weight, which is one of the main determinants of seedling quality, consists of 3 different parts (root, stem and leaf). In the studies conducted, seedlings with high total dry weight have high stomatal conductivity values. Seedlings with balanced root, stem and leaf dry weights have increased resistance to stress conditions. This increase has been associated with high stomatal conductivity. It has been determined that starting cultivation with such seedlings has important effects on yield increase (Özer and Kandemir, 2016; Sarıbaş et al., 2018).

Researchers studying the effects of seaweed fertilizers on most garden and field crops suggests that seaweed enhances the root and offshoot, prompting the vegetative growth (Chanthini et al., 2019). When the leaf weight ratio graphic is analyzed, the highest degree is seen in the SW2 application, ranging from 0.7486 to 0.8329 .

The highest leaf weight was observed on SW2 in seaweed applications (0.8329), while it was 0.7837 on V3 applications of vermicompost (Fig. 1). 
Table 3. Root, leaf and total dry weight values of lettuce seedling

\begin{tabular}{|l|c|c|c|c|}
\hline Application & Root Dry Weight & Leaf Dry Weight & Total Dry Weight & QI \\
\hline SW1 & $0.0305 \mathrm{c}-\mathrm{e}$ & $0.1383 \mathrm{~b}-\mathrm{d}$ & $0.1688 \mathrm{~cd}$ & $0.0961 \mathrm{de}$ \\
\hline SW2 & $0.0476 \mathrm{ab}$ & $0.2372 \mathrm{ab}$ & $0.2848 \mathrm{ab}$ & $0.1555 \mathrm{ab}$ \\
\hline SW3 & $0.0569 \mathrm{a}$ & $0.2556 \mathrm{a}$ & $0.3125 \mathrm{a}$ & $0.1787 \mathrm{a}$ \\
\hline V1 & $0.0338 \mathrm{~b}-\mathrm{e}$ & $0.1043 \mathrm{~cd}$ & $0.1381 \mathrm{~cd}$ & $0.0911 \mathrm{de}$ \\
\hline V2 & $0.0358 \mathrm{~b}-\mathrm{e}$ & $0.1272 \mathrm{~cd}$ & $0.1630 \mathrm{~cd}$ & $0.1023 \mathrm{~cd}$ \\
\hline V3 & $0.0470 \mathrm{ab}$ & $0.1704 \mathrm{a}-\mathrm{d}$ & $0.2174 \mathrm{a}-\mathrm{d}$ & $0.1355 \mathrm{bc}$ \\
\hline V1 + SW1 & $0.0284 \mathrm{de}$ & $0.1234 \mathrm{~cd}$ & $0.1518 \mathrm{~cd}$ & $0.0880 \mathrm{de}$ \\
\hline V1 + SW2 & $0.0350 \mathrm{~b}-\mathrm{e}$ & $0.1287 \mathrm{~cd}$ & $0.1637 \mathrm{~cd}$ & $0.1014 \mathrm{c}-\mathrm{e}$ \\
\hline V1 + SW3 & $0.0404 \mathrm{~b}-\mathrm{d}$ & $0.1825 \mathrm{a}-\mathrm{d}$ & $0.2229 \mathrm{a}-\mathrm{d}$ & $0.1271 \mathrm{~b}-\mathrm{d}$ \\
\hline V2 + SW1 & $0.0361 \mathrm{~b}-\mathrm{e}$ & $0.1076 \mathrm{~cd}$ & $0.1438 \mathrm{~cd}$ & $0.0960 \mathrm{de}$ \\
\hline V2 + SW2 & $0.0446 \mathrm{a}-\mathrm{c}$ & $0.1493 \mathrm{~b}-\mathrm{d}$ & $0.1938 \mathrm{~b}-\mathrm{d}$ & $0.1243 \mathrm{~b}-\mathrm{d}$ \\
\hline V2 + SW3 & $0.0442 \mathrm{a}-\mathrm{c}$ & $0.1687 \mathrm{a}-\mathrm{d}$ & $0.2129 \mathrm{a}-\mathrm{d}$ & $0.1301 \mathrm{bc}$ \\
\hline V3 + SW1 & $0.0380 \mathrm{~b}-\mathrm{e}$ & $0.1541 \mathrm{a}-\mathrm{d}$ & $0.1921 \mathrm{~b}-\mathrm{d}$ & $0.1146 \mathrm{~cd}$ \\
\hline V3 + SW2 & $0.0416 \mathrm{~b}-\mathrm{d}$ & $0.1699 \mathrm{a}-\mathrm{d}$ & $0.2114 \mathrm{a}-\mathrm{d}$ & $0.1257 \mathrm{~b}-\mathrm{d}$ \\
\hline V3 + SW3 & $0.0411 \mathrm{~b}-\mathrm{d}$ & $0.2018 \mathrm{a}-\mathrm{c}$ & $0.2429 \mathrm{a}-\mathrm{c}$ & $0.1335 \mathrm{bc}$ \\
\hline Control & $0.0254 \mathrm{e}$ & $0.0935 \mathrm{~d}$ & $0.1189 \mathrm{~d}$ & $0.0736 \mathrm{e}$ \\
\hline
\end{tabular}

a-e: Means within each row with different letters are significantly different $(\mathrm{p}<0.05)$

Demirsoy and Uzun (2019) detected the leaf weight ratio of the aubergine seedlings he grew in different circumstances to range from 0.45 to 0.67 in his study.

Seaweed extract enables plants to absorb the nutrients in the soil in a balanced and long lasting pattern, enhancing the crop quality, just like improving the ramification and fruit attachment in trees. Likewise, it reduces defloration and fruit loss, yielding a crop surplus by $30 \%$ (Ahmed and Shalaby, 2012). Highest quality index of seedlings was determined in SW3 applications (0.1787). The lowest QI values were determined 0.0736 in the control application. Öztekin and Kevser (2019), reported that the seedling quality index varied between 0.019 and 0.129 in lettuce seedling.

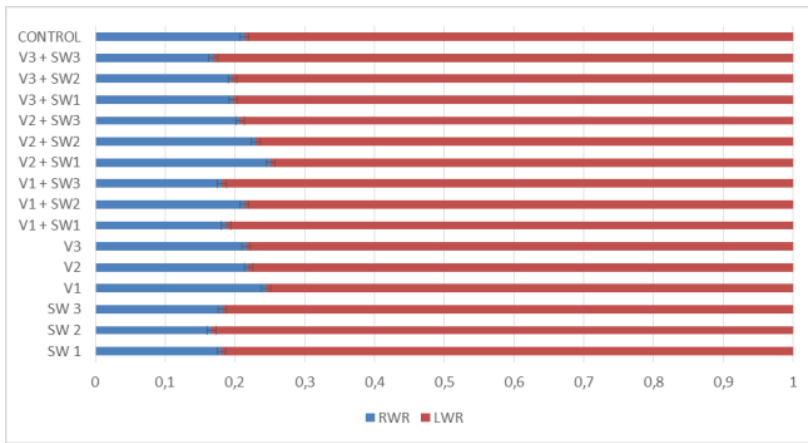

Figure 1. Root weight ratio (RWR) and Leaf weight ratio (LWR) change in lettuce seedling

\section{Conclusion}

Readymade seedling has a great economic sector that increases day by day. Of all the products whose seedlings are readymade the most in our country, lettuce ranks the second. A great many researches assert that what matters most in healthy seedling production is using supplementary agents just after germination. To this end, various chemical and synthetic materials are exploited. As far as the organic farming regulations are concerned, the outlaw of such supplementary chemicals or growth regulators bears a great hurdle standing before cultivation, causing grave economic losses. If the growth phases of the lettuce seedlings are taken into account, statistical discrepancies between the applied materials and their doses emerge. Especially the increase in the dry weight of the root and leaves after the individual uses of seaweed and vermicompost reveals the direct and positive outcomes of the fertilizing materials on the seedling growth.

The fact that both materials promote the absorption of the nutrients in the soil necessarily assures the root to thrive better. Much as seaweed provided the lowest root weight ratio, it yields the highest leaf weight. The lowest root weight ratio is 0.1671 in SW2 application, whereas the highest leaf weight is 0.8329 in SW2. As a result of the trials, SW3 application shines out on the basis of the total dry weight $(0.3125)$ of the lettuce seedlings. The study highest QI was determined in SW3 applications (0.1787). With respect to the leaf weight ratio properties, being an important criterion for the lettuce itself and the dry matter for the seedling quality, seaweed applications have been concluded to be advisable.

\section{Acknowledgement}

We would like to thank the Selcuk University Scientific Research Coordinator for their contributions (17401139).

\section{Authors' Contributions}

M Demirsoy and M. Aydın contributed equally to data acquisition, statistical analysis, data evaluation, conception and design of the study.

\section{Conflict of Interest}

The authors declare that they have no conflict of interest. 


\section{References}

Ahmed, Y., \& Shalaby, E. (2012). Effect of different seaweed extracts and compost on vegetative growth, yield and fruit quality of cucumber. J. Hortic. Sci. Orna. Plants, 4(3), 235-240.

Akyurt, İ., Şahin, Y., \& Hasan, K. (2011). Deniz marulunun (Ulva sp.) sıvı organik gübre olarak değerlendirilmesi. Karadeniz Fen Bilimleri Dergisi, 2(2), 55-62.

Anonymous. (2020). Tarım işletmeleri genel müdürlüğü tohumculuk sektör politika belgesi 2018-2022. Retrieved from http://www.tigem.gov.tr

Arancon, N.Q., Edwards, C. A., Lee, S., \& Byrne, R. (2006). Effects of Humic Acids from Vermicomposts on Plant Growth. European Journal of Soil Biology, 42, 65-69.

Chanthini, K. M.-P., Senthil-Nathan, S., Stanley-Raja, V., Thanigaivel, A., Karthi, S., Sivanesh, H., \& Soranam, R. (2019). Chaetomorpha Antennina (Bory) Kützing Derived Seaweed Liquid Fertilizers as Prospective BioStimulant for Lycopersicon Esculentum (Mill). Biocatalysis and Agricultural Biotechnology, 20, 101190.

Demir, N., Dural, B., \& Yıldırım, K. (2006). Effect of Seaweed Suspensions on Seed Germination of Tomato, Pepper and Aubergine. J Biol Sci, 6(6), 1130-1133.

Demirsoy, M., \& Uzun, S. (2019). The Quantitative Effects of Different Growing Media on the Growth of Aubergine (Solanum melongena L.) and Cucumber (Cucumis sativus L.) in Autumn. International Journal of Environmental Trends (IJENT). 3(2), 151-158.

Demirtaş, E.I., Özkan, C.F., Asri, F. Ö., \& Nuri, A. (2012). Bazı Organik ve Kimyasal Gübre Uygulamalarının Domateste Verim ve Kalite Üzerine Etkileri. Alatarım, 11(2), 9-16.

Dickson, A., Leaf, A.L., \& Hosner, J.F. (1960). Quality appraisal of white spruce and white pine seedling stock in nurseries. The Forestry Chronicle, 36(1), 10-13.

Duan, E. (2013). Bazı Deniz Makro alglerinden (Ulva sp., Cystoseira sp. ve Corallina sp.) Fermente S1v1 Organik Gübre Üretimi ve Taze Fasülye (Phaseolus vulgaris) Verimine Etkisinin Belirlenmesi. (Yüksek Lisans), Giresun Üniversitesi, Giresun. (380607)

Godlewska, K., Michalak, I., Tuhy, L., \& Chojnacka, K. (2016). Plant growth biostimulants based on different methods of seaweed extraction with water. BioMed research international, 2016, 1-11.

Gutiérrez-Miceli, F.A., Santiago-Borraz, J., Molina, J.A.M.,
Nafate, C.C., Abud-Archila, M., Llaven, M.A.O., \& Dendooven, L. (2007). Vermicompost as a soil supplement to improve growth, yield and fruit quality of tomato (Lycopersicum esculentum). Bioresource Technology, 98(15), 2781-2786.

Hameeda, B., Harini, G., Rupela, O., \& Reddy, G. (2007). Effect of composts or vermicomposts on sorghum growth and mycorrhizal colonization. African Journal of Biotechnology, 6(1), 009-012.

Kandemir, D., Kurtar, E. S., \& Demirsoy, M. (2017). Türkiye örtüaltı domates yetiştiriciliğindeki gelişmeler. Türktob Türkiye Tohumcular Birliği Dergisi, 17, 22-27.

Mzibra, A., Aasfar, A., El Arroussi, H., Khouloud, M., Dhiba, D., Kadmiri, I. M., \& Bamouh, A. (2018). Polysaccharides extracted from moroccan seaweed: a promising source of tomato plant growth promoters. Journal of Applied Phycology, 30(5), 2953-2962.

Özer, H., \& Kandemir, D. (2016). Evaluation of the performance of greenhouse tomato seedlings grown with different cultivation techniques. Bangladesh Journal of Botany, 45(1), 203-209.

Öztekin, G.B., \& Kevser, T. (2019). tam spektrumlu gün ışı̆̆ı floresan lamba ile yapay ışıklandırmanın marulda fide kalitesine etkisi. Ege Üniversitesi Ziraat Fakültesi Dergisi, 56(4), 437-445.

Sarıbaş, H. Ş., Saka, A.K., \& Özer, H. (2018). Mathematical growth model for organically grown pepper transplants. Biological Agriculture \& Horticulture, 34(1), 10-17.

TUIKK. (2020). Turkish Statistical Institute Statistical Data (https://biruni.tuik.gov.tr /medas/?kn=92\&locale=tr,).

Türkmen, M., \& Su, A. (2019). The effect of sea lettuce (Ulva lactuca) liquid fertilizer and zeolite combinations on the development of cucumber (Cucumis sativus). Turkish Journal of Agriculture-Food Science and Technology, 7(7), 1021-1027.

Uzun, S. (1996). The Quantitative Effects of Temperature and Light Environment on the Growth, Development and Yield of Tomato (Lysopersicon Esculentum, Mill) and Aubergine (Solanum Melongena L.). University of Reading, England.

Yanmaz, R., Balkaya, A., Akan, S., Kaymak, H. Ç., Sarıkamış, G., Önal Ulukapı, K., \&Açıkgöz, F. E. (2020). Sebzecilik Sektörü: Dünü, Bugünü ve Geleceği. Türkiye Ziraat Mühendisliği IX. Teknik Kongresi, Ankara. s595607 